\title{
AKUNTANSI SUMBER DAYA MANUSIA: KAJIAN KRITIS ATAS PENGAKUAN PEMAIN SEPAK BOLA SEBAGAI ASET KLUB SEPAK BOLA DI INDONESIA
}

\author{
Jadzil Baihaqi \\ Pascasarjana Fakultas Ekonomi dan Bisnis Universitas Brawijaya Malang \\ Jl. MT. Haryono 165 Malang; Telp. 081386639858 \\ e-mail: wabilkhusus21@gmail.com
}

Abstract

The purpose of this study is to examine and criticize the theory of human resource accounting and IAS 38, specificly with regard to the football player recognition. This study also expands the accounting perspective to see the reality of a more holistic perspective, which is not only limited to the financial perspective. This study is a qualitative study by using the critical paradigm and a case study perspective. The result of this study is the form of new accounting concept, particularly the recognition of football players. Player recognition is not interpreted only from the economic perspective, but more important is the players have inherent factors, namely the spiritual factors, education/training, social/cultural, and environmental. These factors highly influence the player, so it does not suitable if the player is recognized as an asset and the monetary valuation is not always the best indicator.

Keywords: human resource accounting, football player, asset

Abstrak

Tujuan dari penelitian ini adalah untuk mengkaji dan mengkritisi teori human resource accounting dan IAS 38 secara mendalam khusus berkenaan dengan pengakuan pemain sepak bola. Penelitian ini juga berupaya untuk memperluas perspektif akuntansi untuk melihat realitas dari sudut pandang yang lebih holistik, tidak terbatas pada perspektif keuangan saja. Penelitian ini merupakan penelitian 
kualitatif, menggunakan paradigma kritis dan menggunakan perspektif studi kasus. Hasil dari penelitian ini berupa konsep baru tentang akuntansi, khususnya pengakuan pemain sepak bola. Pengakuan pemain tidak dimaknai dari perspektif ekonominya saja, melainkan yang lebih penting adalah pemain memiliki faktorfaktor yang melekat pada dirinya, yaitu faktor spiritual, pendidikan/pelatihan, sosial/budaya, dan lingkungan. Faktor-faktor tersebut sangat berpengaruh kepada pemain, sehingga tidak pas bila pemain diakui sebagai aset dan satuan moneter tidak selalu menjadi indikator terbaik.

Kata kunci: akuntansi sumber daya manusia, pemain sepak bola, aset

\section{PENDAHULUAN}

Pola bisnis berbasis skill mengiringi pola industri berbasis pengetahuan (knowledge base), salah satunya yaitu industri olah raga. Olah raga yang paling populer di masyarakat dunia yaitu sepak bola. Olah raga sepak bola pun kini telah menjelma menjadi lahan bisnis baru yang menjanjikan, tidak hanya sebagai hobi. Terdapat keunikan pada industri sepak bola, yaitu masalah akuntansi yang melekat di dalamnya, terutama yang berkaitan dengan pengakuan dan pengungkapan pemain di dalam laporan keuangan klub. Contoh dari pengakuan pemain sebagai aset (players registration dan intangible asset) dapat dilihat dari laporan keuangan klub sepak bola di Inggris dan Jerman sebagai berikut:

\begin{tabular}{|c|c|c|c|}
\hline \multicolumn{4}{|c|}{ Consolidated balance sheet } \\
\hline & \multirow[b]{2}{*}{ Note } & \multicolumn{2}{|c|}{ As of 30 June } \\
\hline & & $\begin{aligned} 2013 \\
\mathbf{E}^{\prime} 000 \\
\end{aligned}$ & $\begin{array}{c}2012(1) \\
f^{\prime} 000 \\
\end{array}$ \\
\hline \multicolumn{4}{|l|}{ ASSETS } \\
\hline \multicolumn{4}{|l|}{ Non-current assets } \\
\hline Property, plant and equipment & 12 & 252,808 & 247,866 \\
\hline Investment property & 13 & 14,080 & 14,197 \\
\hline Goodwill & 14 & 421,453 & 421,453 \\
\hline Players" registrations & 15 & 119,947 & 112,399 \\
\hline Trade and other receivables & 18 & 1,583 & 3,000 \\
\hline \multirow[t]{2}{*}{ Deferred tax asset } & 26 & 145,128 & 二 \\
\hline & & 954,999 & 798,915 \\
\hline
\end{tabular}

Gambar 1. Balance Sheet Manchester United FC

(diambil dari www.manutd.com) 


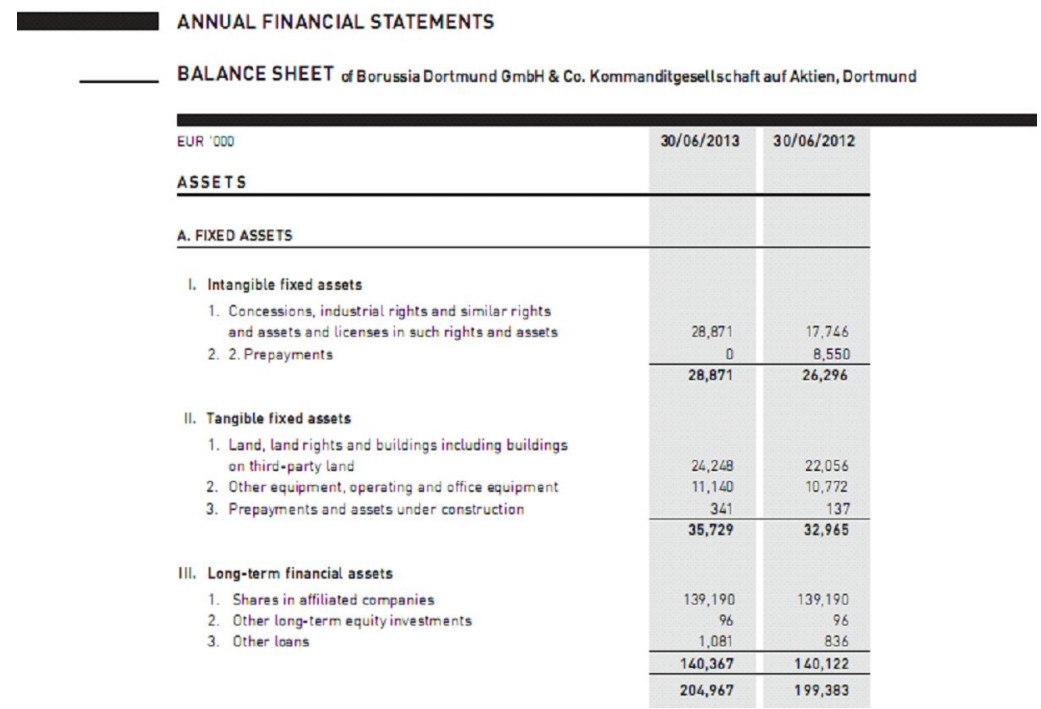

Gambar 2. Balance Sheet Borussia Dortmund FC

(diambil dari www.bvb.de)

Sepak bola di Inggris dan negara-negara eropa telah menjadi industri bisnis. Klub sepak bola di sana telah berbentuk perusahaan publik. Mereka dituntut agar mampu mempertanggungjawabkan dan melaporkan segala bentuk pengelolaan dana dari seluruh aktivitas yang dilakukan secara terbuka dan transparan dalam bentuk informasi yang disajikan dalam laporan keuangan, sehingga mau tidak mau harus menggunakan IFRS (IAS) sebagai standar dalam menyusun laporan keuangan. Tidak heran jika pemain sepak bolanya diakui sebagai aset.

Telah banyak penelitian tentang akuntansi sumber daya manusia pada klub sepak bola seperti (Goshunova, 2013), (Siddik \& Chariri, 2013), (Oprean \& Oprisor, 2013), (Amir \& Livne, 2005), (Devi, 2004). Dalam penelitian-penelitian tersebut, akuntansi merupakan alat untuk menyajikan informasi klub sepak bola. Penelitianpenelitian tersebut semakin menguatkan bahwa pemain sepak bola merupakan aset perusahaan yang disajikan dalam balance sheet dan dinilai berdasarkan metode kapitalisasi atas biaya yang dikeluarkan untuk mendapatkan pemain.

Karakteristik klub sepak bola di Indonesia tentu saja berbeda dengan klub di Inggris dan negara-negara eropa. Klub sepak bola di Indonesia masih berbentuk PT tertutup. Sepak bola di Indonesia tidak diindustrikan walaupun tetap ada komersialisasi seperti sponsor, tiket, marchandise, dan hak siar. Ketentuan laporan keuangan untuk klub sepak bola di Indonesia memang belum ditentukan secara formal oleh PSSI. Sehingga klub sepak bola di Indonesia menggunakan standar ETAP untuk menyusun laporan keuangan, seperti Persema (Siddik \& Chariri, 2013). Muncul permasalahan juga ketika klub sepak bola Indonesia menjadi anggota AFC 
(Konfederasi Sepak Bola Asia) dimana AFC mensyaratkan menggunakan IFRS dalam kriteria penyusunan laporan keuangan.

Mengacu pada pendapat Triyuwono (1998) dalam (Kurniawan, Mulawarman, \& Kamayanti, 2014) yang menjelaskan bahwa praktik akuntansi keuangan ditentukan oleh sosial masyarakat lokal dan faktor budaya. Di Indonesia, sepak bola bukan merupakan industri bisnis yang tidak sama dengan sepak bola di negara barat. Pertanyaan mendasar berkaitan dengan pengakuan pemain (manusia) sebagai aset klub sepak bola (perusahaan) apakah sudah tepat mengingat sifat implisit manusia yang secara fundamental berbeda dengan sumber daya fisik dan keuangan lainnya (The American Accounting Association's Committee on Accounting for Human Resources, 1974 dalam (Johnson, 1990). Rasanya tidak pantas jika pemain di klub sepak bola yang berwujud manusia diakui sebagai aset perusahaan. Dalam diri manusia melekat perasaan, skill, pengetahuan, yang kesemuanya tersebut tidak dapat dimiliki perusahaan. Mendefinisikan tenaga kerja (pemain) sebagai aset (komoditas) perusahaan merupakan bentuk kapitalisme (Neoclassical economist) (Bowles \& Gintis, 1975).

\section{TINJAUAN PUSTAKA}

\section{Human Resource accounting (Akuntansi Sumber Daya Manusia)}

Menurut Flamholtz dalam bukunya "Human Resource Accounting" (1999), dikemukakan sebagai berikut: "Human Resource Accounting means accounting for people as an organizational resources". Artinya: "Akuntansi Sumber Daya Manusia berarti akuntansi untuk manusia sebagai suatu sumber dari organisasi". Hal ini menyangkut tentang biaya-biaya yang dikeluarkan oleh perusahaan dan organisasi yang lain untuk merekrut, memilih, mempekerjakan, melatih, dan mengembangkan human assets yang juga berhubungan dengan nilai ekonomis dari pekerja/pegawai organisasi.

Hermanson (1964) merupakan orang yang pertama mencoba memasukkan modal manusia dalam neraca yang dikenal sebagai akuntansi sumber daya manusia. Pendekatan awal akuntansi sumber daya manusia digambarkan sebagai proses tentang pengidentifikasian, pengukuran dan pengkomunikasian informasi akuntansi sumber daya manusia untuk memudahkan efektivitas manajemen dalam suatu organisasi. Hal ini merupakan pengembangan dari prinsip akuntansi atas kesesuaian biaya dan pendapatan terhadap data organisasi untuk mengkomunikasikan informasi lain dalam istilah keuangan. Hal ini juga melibatkan pengukuran nilai ekonomi dari manusia terhadap organisasi.

Keprihatinan utama dari Hermanson adalah bahwa laporan keuangan konvensional gagal untuk mencerminkan dengan memadai posisi keuangan dari suatu perusahaan karena laporan tersebut tidak memasukkan aktiva manusia. Hermanson mengembangkan "metode goodwill yang tidak terbeli" untuk mengukur nilai dari 
aktiva manusia yang dikembangkan oleh suatu perusahaan melalui operasi normal (perekrutan, pelatihan, dan seterusnya) dibandingkan dengan apa yang dibeli melalui akuisisi terhadap perusahaan lain.

Eksperimentasi pertama dalam organisasi yang sesungguhnya dengan pengukuran nilai sumber daya manusia dilaksanakan oleh (Flamholtz, 1969) sebagai dasar bagi disertasi doktornya yang berjudul "The theory and measurement of an individual's value to an organization". Akuntansi sumber daya manusia adalah suatu pengakuan bahwa orang-orang merupakan modal manusia maupun aktiva manusia. Teori ekonomi dari modal manusia didasarkan pada konsep bahwa manusia memiliki keterampilan, pengalaman, dan pengetahuan yang merupakan bentuk dari modal yang disebut dengan " human capital".

Schultz (1961) menyatakan bahwa "para pekerja telah menjadi kapitalis tidak hanya dari difusi kepemilikan saham perusahaan sebagaimana yang terjadi dalam dongeng, tetapi dari akuisisi pengetahuan dan keterampilan yang memiliki nilai ekonomi. Akuntansi sumber daya manusia juga telah mengembangkan dari tradisi yang paralel dalam manajemen karyawan yang dikenal sebagai "aliran sumber daya manusia" yang didasarkan pada pemikiran bahwa manusia adalah sumber daya organisasional yang berharga dan oleh karena itu harus dikelola sebagai sumber daya yang berharga.

Konsep human capital pada intinya menganggap bahwa manusia merupakan suatu bentuk modal atau kapital sebagaimana bentuk-bentuk kapital lainnya, seperti mesin, teknologi, tanah, uang, dan material. Manusia sebagai human capital tercermin dalam bentuk pengetahuan, gagasan (ide), kreativitas, keterampilan, dan produktivitas kerja. Tidak seperti bentuk kapital lain yang hanya diperlakukan sebagai tools, human capital ini dapat menginvestasikan dirinya sendiri melalui berbagai bentuk investasi SDM, diantaranya pendidikan formal, pendidikan informal, pengalaman kerja, kesehatan, dan gizi serta transmigrasi (Fattah, 2004).

\section{IAS 38}

IAS 38 adalah standar akuntansi yang dikeluarkan oleh IASB yang memberikan aturan dan pedoman akuntansi untuk aset tak berwujud (intangible asset). Isu yang ada dalam IAS 38 adalah pengklasifikasian aset yang tak berwujud, pengakuan dan pengukurannya, serta pengungkapannya. Intangible asset merupakan aset non moneter yang dapat teridentifikasi tanpa substansi fisik (tidak berwujud). Sesuatu dapat diakui sebagai intangible asset jika definisi intangible asset dan kriteria pengakuan telah terpenuhi. Aset dapat diidentifikasikan jika dapat dipisahkan dan muncul dari kontrak atau perjanjian lainnya. Intangible asset akan diakui jika dimungkinkan memiliki perkiraan manfaat ekonomi di masa yang akan datang yang dilekatkan kepada aset dan selanjutnya kepada entitas, serta biaya atas aset dapat diukur dengan andal. 
IAS 38 menyebutkan bahwa suatu aset tak berwujud harus diakui sebesar biaya perolehannya. Jumlah yang dapat diamortisasi atas suatu aset tidak berwujud harus dialokasikan secara sistematis atas umur manfaat aset tersebut. Amortisasi dapat dimulai sejak aset tersebut telah ada dan siap untuk digunakan dan metode yang digunakan harus mencerminkan pola di mana manfaat ekonomi masa mendatang atas suatu aset dapat diterima oleh perusahaan.

IAS 38 menjelaskan bahwa suatu aset tak berwujud harus dihentikan pengakuannya jika aset tersebut telah dihapuskan dan tidak ada manfaat ekonomis yang dapat diterima perusahaan atas penghapusan aset tersebut. Keuntungan atau kerugian yang timbul dari penghentian pengakuan aset tidak berwujud tersebut ditentukan dari perbedaan antara jumlah neto hasil pelepasan dengan jumlah tercatat atas aset tersebut. Selisih tersebut harus diakui dan dilaporkan dalam Laporan Laba rugi.

\section{Kerangka Pelaporan dalam Industri Sepak Bola Informasi Pelaporan Umum untuk Klub Sepak Bola}

Ada kriteria yang tercantum dalam perizinan UEFA Club dan Peraturan Financial Fair Play yang telah terintegrasi dalam peraturan sepak bola nasional. Pemantauan pemenuhan kriteria ini dilakukan secara tahunan dan Lisensor (pemberi lisensi) harus memeriksa secara menyeluruh semua aspek, sesuai dengan peraturan yang telah disebutkan.

Pada dasarnya, peraturan menyatakan bahwa sebuah klub sepak bola (yang sedang dilisensikan) harus memenuhi 5 kriteria khusus, yaitu: kriteria olahraga (pembangunan pemuda, perawatan medis, pendaftaran pemain, seminar kehadiran dan persamaan ras), kriteria infrastruktur (stadion dan fasilitas pelatihan), personil dan kriteria administrasi (persyaratan untuk sumber daya manusia), kriteria hukum (kontrak tertulis, struktur kelompok hukum dan pihak pengendali utama) dan kriteria keuangan (laporan perimeter, tahunan dan interim laporan keuangan, Status hutang dan informasi keuangan di masa depan).

Sesuai dengan kriteria keuangan, klub sepak bola harus menerapkan peraturan akuntansi internasional dan peraturan pelaporan keuangan (dengan rujukan ke International Financial Reporting Standards). Dengan demikian, klub harus mempersiapkan dan menyampaikan laporan keuangan tahunan yang telah diaudit kepada Pemberi Lisensi, dalam rangka untuk menilai tingkat kepatuhan terhadap peraturan mengenai pelaporan keuangan. Dalam kasus khusus - ketika batas waktu penyerahan melebihi 6 bulan, laporan keuangan interim juga diperlukan.

\section{Pilihan (Bentuk) Penilaian untuk Kontrak Pemain Sepak Bola}

Pengungkapan agen bebas dan pemain muda dalam laporan keuangan berpotensi memunculkan masalah, karena fakta bahwa tidak ada dasar yang kuat untuk 
penilaian dan tidak ada pasar aktif untuk parameter yang sebanding (untuk memasukkan nilai yang kredibel). Namun, kasus khusus ini telah menyusun alat metode akuntansi dan penilaian yang dikembangkan oleh teori dalam literatur. Lebih spesifik, dua dari teori-teori ini telah terbukti relevan, yaitu teori milik Jan-Erik Grõjer dan Eric Flamholtz (Oprean \& Oprisor, 2013).

Dalam teori pertama, Grõjer menyatakan bahwa salah satu pilihan untuk mengevaluasi aset tidak berwujud terhubung ke modal intelektual yang dapat dilakukan melalui kapitalisasi upah. Jenis penilaian ini dianggap memadai untuk agen bebas, di mana upah yang dinegosiasikan akan dianggap tepat sebagai dasar penilaian. Namun teori ini memiliki kelemahan, yaitu pengakuan dari perbedaan nilai antara agen bebas dan pemain akan mengarah pada overvaluation aset (tanpa kepastian cash-in).

Di sisi lain, teori Flamholtz menyatakan bahwa biaya perekrutan dapat dikaitkan kepada kontrak karyawan. Dalam kasus khusus ini, biaya perekrutan dapat dengan mudah diidentifikasi untuk akademi, dalam set informasi yang diminta oleh Pemberi Lisensi (biaya pelatihan, personil, biaya fasilitas dll). Masalah bagi teori ini adalah bahwa biaya ini ditentukan secara global, untuk seluruh akademi dan distribusi tiap pemain - untuk penilaian tujuan - dilakukan hanya untuk pemain yang memilih untuk menandatangani kontrak profesional (Aronsson, et al., 2004 dalam (Oprean \& Oprisor, 2013)).

Teori ini lebih memadai dalam penilaian pemain dari pada teori milik Grõjer, karena dalam nilai yang telah ditentukan ada perbandingan antara biaya dengan pengembangan, serta peningkatan kinerja. Selain itu, persyaratan pengungkapan yang ditetapkan oleh UEFA dan FIFA (khususnya, dalam catatan penjelasan) mengatur kerangka kerja bagi klub lain untuk menggunakan informasi ersebut sebagai bahan dalam proses penilaian.

\section{Format Laporan Keuangan yang disyaratkan oleh UEFA}

Berdasarkan aturan yang dikeluarkan oleh (UEFA, 2012) - UEFA Club Licensing and Financial Fair Play Regulation mengatur tentang penyajian minimum laporan keuangan klub, yaitu balance sheet, profit and loss, cash flow statement, dan notes. Di samping itu, UEFA juga menyaratkan pencantuman Financial review by management dalam setiap pelaporan keuangan masing-masing klub. Untuk lebih jelasnya dapat digambarkan sebagai berikut: 
Laporan keuangan yang diatur dalam UEFA Financial Criteria

\begin{tabular}{llll}
\hline \multicolumn{1}{c}{ Balance Sheet } & Profit and Loss & \multicolumn{1}{c}{ Cash Flow Statement } & Notes \\
\hline Current Assets & Revenue & Cash flows from operating activities & Notes \\
Non-current Assets & Expenses & Cash flows from investing activities & \\
Current Liabilities & Other & Cash flows from financing activities & \\
Non-Current Liabilities & & Other cash flows & \\
Net assets/liabilities & & & \\
Equity & & & \\
\hline
\end{tabular}

Sumber: UEFA Club Licensing and Financial Fair Play Regulation Edition 2012.

\section{Gambar 4. Format laporan keuangan UEFA}

(dikutip dari (Siddik \& Chariri, 2013))

\section{METODE PENELITIAN}

Penelitian ini menggunakan paradigm kritis. Melalui pendekatan kritis, suatu teori bukan hanya dilihat pada upaya menempatkan ideologi sebagai bentuk pemikiran, akan tetapi juga akan mencoba mengkajinya. Teori kritis mempunyai komitmen yang tinggi kepada tata sosial yang lebih adil (Muhadjir, 2000). Penelitian akuntansi berbasis paradigma kritis berusaha untuk menjelaskan bahwa teori dan praktik akuntansi dapat berkembang terus sesuai dengan kreatifitas peneliti dalam akuntansi yang bertujuan melakukan kritik, transformasi, pemulihan, emansipasi, pembongkaran terhadap suatu fenomena yang diteliti agar dapat dipahami lebih baik (Riharjo, 2011). Sedangkan perspektif yang digunakan dalam penelitian ini adalah studi kasus (case study). Studi kasus merupakan suatu penelitian empiris yang menyelidiki keadaan yang terjadi pada masa sekarang dalam realita kehidupan yang bersifat nyata, ketika batas antara gejala dengan latar tidak secara jelas terbukti, dan bila mana berbagai sumber bukti digunakan (Yin, 2004).

Jenis data yang digunakan dalam penelitian ini adalah data sekunder yang diperoleh peneliti melalui studi literatur baik berupa jurnal penelitian dan media lainnya yang menyajikan informasi yang berkaitan dengan masalah penelitian.

\section{PEMBAHASAN}

\section{Gambaran Klub Sepak Bola di Indonesia}

Dalam penelitian ini, peneliti mengambil gambaran klub sepak bola di Indonesia dari penelitian (Siddik \& Chariri, 2013) yang mengambil setting klub sepak bola Persema. Diharapkan dari salah satu klub sepak bola ini dapat mewakili dari gambaran klub sepak bola di Indonesia. Persema (Persatuan Sepak Bola Malang) adalah klub yang berdiri di Kota Malang. Klub sepak bola berjuluk "Laskar Ken Arok" ini didirikan pada tanggal 20 Juni 1953 yang merupakan klub sepak bola 
milik Pemerintah Kota Malang. Sebagai klub sepak bola, Persema bermarkas di Stadion Gajayana dan memiliki pendukung fanatik bernama Ngalamania.

Tampil pertama kali di jenjang teratas Liga Indonesia, Persema tidak pernah meraih gelar apapun. Sejak tampil di pentas Liga Indonesia pada musim kompetisi 1994/1995, prestasi terbaik Persema hanyalah menempati peringkat ke empat di grup D pada musim kompetisi 1998/1999. Selebihnya, Persema selalu berada di papan tengah dan bahkan tidak jarang berada di papan bawah klasmen liga. Akhirnya, pada musim kompetisi 2009/2010, Persema kembali berlaga di Liga Super Indonesia (LSI) setelah memastikan diri menjadi runner up Divisi Utama musim 2008/2009. Pada tahun 2011, Persema menyatakan keluar dari LSI yang merupakan kompetisi tertinggi yang diselenggarakan dan diakui secara resmi oleh PSSI pada saat itu. Persema kemudian lebih memilih untuk bergabung dengan Liga Primer Indonesia (LPI) yang merupakan liga tandingan dari LSI tersebut. Persema adalah salah satu klub Liga Super Indonesia yang memutuskan menarik diri LSI dan bergabung dengan LPI untuk mewujudkan cita-cita sebagai klub sepak bola Indonesia yang mandiri. Sejak akhir tahun 2010, Persema yang telah diakuisisi oleh pihak konsorsium dari Pemerintah kota Malang kini telah sepenuhnya berada di bawah pengelolaan PT Singosari Sakti Indonesia. Konsorsium LPI mulai mengendalikan Persema sejak bergulirnya IPL tahun 2011 berikut masalah pendanaan klub.

Mengutip dari penelitiannya (Siddik \& Chariri, 2013), dari wawancara yang dilakukan kepada pihak Persema, terungkap fakta-fakta di balik aktivitas pelaporan keuangan klub. Wawancara yang dilakukan terhadap CEO dan Manajer Keuangan PT Singosari Sakti Indonesia menghasilkan beberapa hal penting terkait dengan aktivitas pelaporan keuangan klub, yaitu:

1. Persema berpedoman kepada SAK ETAP, dan mengacu pada AFC Financial Regulation dalam menyusun laporan keuangan.

2. Pihak-pihak yang memengaruhi informasi keuangan Persema diantaranya CEO, manajer keuangan, direktur operasional, dan pihak konsorsium.

3. Ada tiga pihak utama yang memiliki kepentingan terkait dengan pemenuhan akuntabilitas klub, yakni pihak konsorsium, pemain, dan pemerintah.

4. Pihak klub telah memiliki pendelegasian wewenang yang jelas pada Departemen Keuangan untuk menangani hal-hal yang terkait keuangan klub dan penyusunan laporan keuangan.

5. Penyusunan laporan keuangan dilakukan dengan pencatatan bukti-bukti transaksi, yang diikuti pemostingan ke buku besar. Setiap akhir bulan, perusahaan juga melakukan rekonsiliasi bank dan penjurnalan. Ini dilakukan sekaligus untuk memeriksa kembali segala transaksi yang ada di bank yang kemudian dicocokkan dengan catatan perusahaan. Sedangkan penjurnalan dilakuan untuk menyesuaikan transaksi-transaksi tertentu yang terjadi terkait dengan rekonsiliasi yang dilakukan. Setelah itu, penyusun laporan keuangan dilakukan. Proses 
penyusunan laporan keuangan ini akan berlanjut pada pengonversian laporan tersebut ke format laporan yang diminta AFC.

6. Persema tidak melibatkan pihak lain dalam menyusun laporan keuangan, melainkan hanya permasalahan yang terkait dengan pajak.

7. Meskipun tidak direncanakan untuk waktu dekat, namun Persema sendiri memiliki keinginan untuk bisa go public.

\section{Industrialisasi Sepak Bola Indonesia: Sudah Tepat kah?}

Di Eropa dan Inggris, sepak bola telah menjadi sebuah industri bisnis yang menghasilkan uang. Klub sepak bola telah berstatus perusahaan terbuka dan sahamnya telah listing di bursa. Maraknya industri persepakbolaan akhir-akhir ini telah melahirkan klub-klub raksasa dengan penghasilan yang luar biasa, yaitu melebihi US\$ 200 juta pertahun. Pendapatan yang sangat tinggi ini berasal dari tiket pertandingan, penjualan hak siar kepada industri media, sponsorship, dan penjualan merchandise klub di seluruh dunia. Untuk mencapai penghasilan yang tinggi tersebut, masing-masing klub berlomba-lomba untuk meningkatkan nama klubnya dengan membentuk tim sepak bola terbaik. Targetnya adalah memperoleh kemenangan dalam pertandingan dan menjadi juara di berbagai kompetisi. Menjadi juara berarti meningkatkan citra klub, menarik sponsor, meningkatkan harga hak siar, dan mendapatkan pemasukan dari hadiah. Selain itu, penggemar akan semakin banyak dan imbasnya penjualan tiket dan merchandise klub semakin meningkat. Jika pendapatan naik, nama klub bagus, dan pendukung banyak, maka nilai perusahaan akan meningkat.

Jika seperti itu, maka yang paling diuntungkan adalah shareholder. Format industri sepak bola ini sangat menguntungkan pihak pemilik modal. Pemilik modal bisa saja memiliki klub dengan membeli mayoritas sahamnya. Pemilik modal akan bisa melakukan apapun terhadap klub sepak bola yang dimiliki, seperti "menjual" atau "membeli" pemain tanpa mempertimbangkan faktor lainnya. Yang ada hanyalah pemikiran bagaimana menghasilkan uang dan kesenangan.

Sepak bola di Indonesia berbeda format dengan sepak bola di eropa atau Inggris. Di Indonesia, sepak bola masih belum diindustrikan. Klub sepak bola tidak berupa perusahaan terbuka. Malah masih ada yang dikelola pemerintah daerah. Namun upaya menuju kesana sudah banyak dikaji oleh berbagai pakar, baik dari pakar keolahragaan, bisnis, dan akademisi dengan penelitiannya yang beraliran positivis yang arahnya menuju industrialisasi sepak bola. Sepak bola Indonesia sesungguhnya mengandung banyak nilai, diantaranya adalah persatuan, kebersamaan, dan spiritual.

Melihat nama-nama klub sepak bola di Indonesia ada yang menarik, yaitu sebagian besar berawalan "Persatuan Sepak bola", contohnya Persema (Persatuan Sepak Bola Malang). Persatuan menunjukkan bersatunya seluruh elemen 
masyarakat pecinta sepak bola, baik berwujud pemain maupun supporter yang menggambarkan karakter daerah tertentu. Seolah-olah klub sepak bola tersebut milik masyarakat daerah tersebut. Banyaknya dan fanatisnya supporter merupakan wujud kecintaan masyarakat terhadap klub sepak bola daerahnya.

Keberadaan Pemain dan supporter dalam sebuah klub tidak dapat dielakkan. Pemain merupakan aktor utama dalam klub sepak bola. Sedangkan supporter adalah pemain ke-12 dari tim sepak bola. Dari pemain, supporter, dan klub sepak bola memunculkan suatu kebersamaan. Contoh nyata adalah ketika Arema sedang mengalami kesulitan keuangan, para supporter menggalang dana demi menjaga keberadaan klub Arema. Selain itu, ketika melihat bagaimana kebersamaan supporter yang akan memberikan dukungan terhadap klubnya, mereka saling membantu, baik memberikan tumpangan, dan memberikan memfasilitasi ketika timnya sedang melakukan pertandingan tandang.

Nilai spiritualitas pada pemain terlihat dari ketaatan terhadap ajaran agama yang dianut dan sikap yang ditunjukkan. Sebagian besar pemain sepak bola di Indonesia beragama Islam, dengan pengaruh lingkungan dan budaya, secara tidak langsung pemain sepak bola di Indonesia memiliki ketaatan yang baik terhadap agama yang dianut. Contohnya adalah ketika tim nasional Indonesia U-19 melakukan pertandingan persahabatan dengan tim negara timur tengah pada tahun 2014 ini sekaligus menjalankan ibadah umroh. Sikap yang ditunjukkan pun mencerminkan kebaikan moral. Tidak seperti pemain di negara barat, mereka kebanyakan gemar minum minuman keras sampai mabuk dan gemar melakukan tindakan asusila.

Saya rasa tidak tepat jika sepak bola di Indonesia dijadikan sebuah industri bisnis. Hal ini akan mengakibatkan musnahnya nilai-nilai budaya lokal sepak bola Indonesia. Mengutip artikel dari (Poernomo, 2011) yang telah melakukan wawancara terhadap supporter yang berisi tentang penolakan industrialisasi sepak bola. Berikut kutipannya:

"Kamilah orang2 yang selalu menonton kehidupan (bukan sekedar olahraga) sepakbola dari sudut pandang mereka yang selalu menyaksikan pertandingan di sektor paling buruk dalam stadion. Dari sudut pandang orang2 yang tidak membutuhkan kenyamanan saat mendukung timnya beratus 2 kilometer dari rumah. Jadi kami adalah supporter, kami adalah ultras.. Kenyataan memang pahit. Sepakbola mulai berubah! Ke arah sebuah industri sepakbola moderen (FUCK OFF.. Kami ga butuh industri sepakbola!!!) Lalu apa yang bisa kita perbuat?? Tak ada! Sebenarnya apa yang menjadi keunggulan sepakbola sehingga bisa menjadi sangat terkenal?? Sebagai sebuah olahraga rasanya tak ada kelebihan yang menonjol dari sepakbola”.

Selain itu, (Poernomo, 2011) juga telah melakukan survei masyarakat kota Jakarta pada tahun 2010 yang hasilnya adalah sebanyak 52\% masyarakat tidak 
setuju apabila sepak bola dijadikan sebuah industri. Mereka mayoritas memang mengatakan bahwa harga tiket yang semakin mahal membuat mereka sulit untuk masuk, bahkan seorang penonton mengatakan selama ini ia harus rela untuk mengutang hanya untuk menonton sepak bola. Bahkan dalam sebuah web ultraspss.info seorang suporter mengatakan:

"Para penonton sepakbola selalu dipandang sebagai sisi buruk kehidupan manusia, Pekerja kelas bawah, anak2 jalanan, gerombolan gangster. ya kaum marginal.. kami sudah disamakan dengan kriminal! Itulah yang kini mereka coba ubah! Menjadikan sepakbola Indonesia menjadi sebuah industri penghasil Uang! Ya uang.. uang adalah segala2nya. Semua tergiur melihat industri sepakbola di eropa, banyak marchendise klub yang laris manis dan menghasilkan uang. Bagaimana mereka bisa merealisasikan ini?? Dengan menyingkirkan kami para supporter, kami yang dianggap menghambat kemajuan sepakbola, ataukah menghambat pemasukan mereka?? Perubahan memang belum tampak tapi indikasi ke arah sana terlihat jelas. Harga tiket yang selalu melambung tinggi belakangan ini bagai sebuah' larangan' bagi supporter dari kalangan bawah untuk datang ke stadion.

Bahkan dari kelompok kami sendiri banyak yang harus utang sanasini untuk dapat sekedar menonton pertandingan di kandang sendiri. Yang lebih mengenaskan adalah tribun sektor khusus supporter mulai dimasuki mereka dari kalangan non-supporter. Pernah dalam suatu pertandingan kami lihat sekeluarga duduk manis di kurva utara!!??? Apa2an ini?? ini daerah kami! ini tempat kami bernyanyi, ini surga kami dimana kami bisa mengekspresikan kebebasan! Kenapa kalian harus duduk disini?? Kini semua orang membicarakan sepakbola, walau masih sekedar sepakbola eropa. Orang2 inilah yang akan menjadi target PSSI untuk masuk ke stadion2 kita.

Mereka yang tau sepakbola dari televisi dan media cetak, mereka yang taunya hanya melihat kehebatan christiano ronaldo dengan gocekan2 mautnya, para perempuan yang menyukai sepakbola hanya karena para pemain di eropa berparas tampan, mereka yang saat ini hanya bisa mencaci maki sepakbola Indonesia. Sepakbola kita kampungan, sepakbola kita kebanyakan ricuh, supporter bola disini ga kaya di inggris yang bisa nonton tertib, sepakbola disini bisanya cuma tawuran, katrok, ndeso dll.. BULL SHIT!!! Tau apa kalian tentang sepakbola??? tau apa kalian tentang supporter?? tau apa kalian tentang semangat, keyakinan, gairah, kehormatan, dan harga diri?? taukah kalian bahwa... di eropa sana korban meninggal akibat sepakbola jauh lebih banyak daripada di negeri 
kita sendiri???? Lebih baik kalian teruskan' dunia sepakbola kalian' sebuah mimpi indah di layar kaca.. karena kenyataanya di lapangan mungkin tak seindah yang kalian bayangkan.

Memang melihat kondisi sepakbola kita, jauh rasanya dari sebuah industri, jauh rasanya dari sepakbola moderen yang diimpikan semua kalangan masyarakat. Apakah kita menuju sebuah industri sepakbola yang nantinya menjadi pemasukan bagi klub kesayangan kita?? Ataukah kita menuju industri untuk mengencangkan sifat mercantilist dari para petinggi sepakbola kita?? Sebagai sumber pemasukan, Sebagai sebuah mesin penghasil uang??? Jangan sampai terjadi!! Sepakbola di sini masih milik kami para supporter! Lalu kenapa kalian mau ambil apa yang kami miliki?? Melambungnya harga tiket pertandingan, Pelarangan menyalakan kembang api, pelarangan memasang spanduk2 yang mengkritik otoritas sepak bola Indonesia, apa yang kalian cari?? Jawabannya uang! Sikap mercantilist yang nantinya akan mematikan kita "para pemilik sepakbola yang sebenarnya!" Jangan ambil kesenangan kami, Jangan ambil hidup kami!"

\section{Pemain Sebagai Aset: Akuntansi Berpihak Kepada Siapa?}

Fakta di lapangan, klub sepak bola di eropa telah mengakui pemain sebagai aset. Lebih tepatnya pada aset tak berwujud (intangible asset). Hal ini dikarenakan secara regulasi yang ditentukan oleh UEFA mewajibkan klub sepak bola untuk menggunakan IFRS sebagai standar dalam menyusun laporan keuangan. Standar yang digunakan secara khusus dalam pengakuan pemain adalah IAS 38 yang mengatur tentang intangible asset. Dalam hal ini, pemain sepak bola di eropa telah memenuhi definisi sebagai intangible asset dilihat dari pengertian dan kriterianya. Sedangkan penilaiannya adalah menggunakan teori human capital yang diajukan oleh Flamholtz. Teori Flamholtz menyatakan bahwa biaya perekrutan dapat dikaitkan kepada kontrak pekerja. Sehingga pemain dinilai sebesar nilai transfernya dan diungkapkan dalam intangible asset.

Masalahnya adalah apakah pantas pemain (manusia) dianggap sebagai aset? Perlu ditelusuri akuntansi ini berpihak kepada siapa? Untuk mencari jawaban dari pertanyaan tersebut, saya menggunakan alat analisis sebagai berikut: 


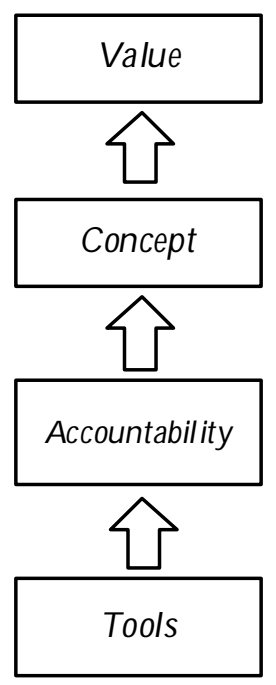

\section{Gambar 5. Alat Analisis Pencarian Keberpihakan Akuntansi}

Tools (alat) akuntansi dalam penelitian ini adalah IFRS di mana akuntansi merupakan alat untuk menyediakan informasi keuangan klub sepak bola. IFRS dapat mengakomodir kepentingan pengungkapan pemain sebagai aset. Pemain dianggap sebagai aset melihat bahwa jika pemain (nilai transfer) dianggap sebagai biaya, maka akan mengurangi laba dan dianggap kurang tepat. Dengan adanya IFRS (IAS 38) dapat mengakui pemain sebagai aset (intangible asset).

Akuntansi pada tataran akuntabilitas menunjukkan apa yang dipertanggungjawabkan dan kepada siapa informasi ini dilaporkan. Akuntansi yang berpedoman pada IFRS hanya mempertanggungjawabkan hal-hal yang bersifat material. Sifat material ini ditunjukkan dengan angka-angka. Dalam kasus ini, angka digunakan untuk menilai pemain. Pemain dinilai hanya menggunakan satuan moneter, padahal ada banyak nilai yang terkandung dalam pemain. Tentu saja nilai pemain ini dibutuhkan oleh shareholder untuk mengetahui berapa kekayaan klub sepak bola. Jika nilai transfer pemain diakui sebagai aset, maka aset perusahaan akan terlihat bernilai besar, padahal nilai itu hanyalah ekspektasi yang dimungkinkan memberikan nilai tambah di masa yang akan datang. Padahal belum tentu demikian, dimana pemain tidak dapat dipastikan bisa bermain bagus dalam waktu yang akan datang.

Konsep yang dihasilkan dari praktik akuntansi (pengakuan pemain sebagai aset) pada klub sepak bola adalah teori human resource accounting (HRA). HRA menganggap bahwa pekerja (pemain) merupakan bagian dari perusahaan yang menghasilkan produktivitas bagi perusahaan. Inti dari teori ini adalah mengakui pekerja sebagai aset perusahaan. Dalam kasus ini adalah pemain diakui sebagai aset perusahaan. Teori ini memperlihatkan suatu bentuk perbudakan, di mana 
manusia disamakan dengan bangunan, mesin, dan aset lainnya. Kecacatan teori ini adalah tidak memperhatikan sifat implisit manusia yang memiliki pengetahuan, bisa berkembang dengan diberikan pelatihan, memiliki hati yang bisa merasakan baik dan buruk, dan mampu melakukan perubahan.

Dari tools, accountability, dan concept yang telah ada, maka nilai yang terkandung dalam praktik akuntansi pengakuan pemain sebagai aset adalah egoisme investor sebagai pemilik klub. Pemilik klub ingin menilai berapa kekayaan yang dia miliki tanpa mempertimbangkan faktor pemain, supporter, masyarakat, apalagi Tuhan. Tuhan tidak ada dalam klub sepak bola. Yang diinginkan hanyalah bagaimana mencari keuntungan sebanyak-banyaknya untuk menuruti ego (nafsu) mereka.

Konsep akuntansi yang diterapkan terhadap pemain sepak bola tidak cukup bila didasarkan pada aspek keuangan saja. Konsep akuntansi akan menemui banyak keterbatasan saat diaplikasikan dalam pemain sepak bola. Saya berpendapat bahwa konsep akuntansi dalam pemain sepak bola bisa diperluas, tidak hanya berdasarkan aspek keuangan, tetapi lebih didasarkan pada beberapa faktor yang melekat pada pemain sepak bola. Konsep akuntansi harus diperluas dalam hal pengakuan selain pada aset dan biaya.

Dalam pemain tidak hanya terkandung sebuah nilai yang bisa diukur dengan angka. Ada banyak faktor terkait dengan pemain sepak bola yang menjadikannya bisa bermain sepak bola pada suatu klub. Faktor-faktor tersebut membentuk pemain yang dalam kasus ini dianggap sebagai aset yang dinilai berdasarkan nilai kontraknya. Faktor tersebut meliputi faktor spiritual, pendidikan/pelatihan, sosial/ budaya, dan lingkungan. Faktor tersebut dapat mempengaruhi pemain sebagaimana digambarkan sebagai berikut:

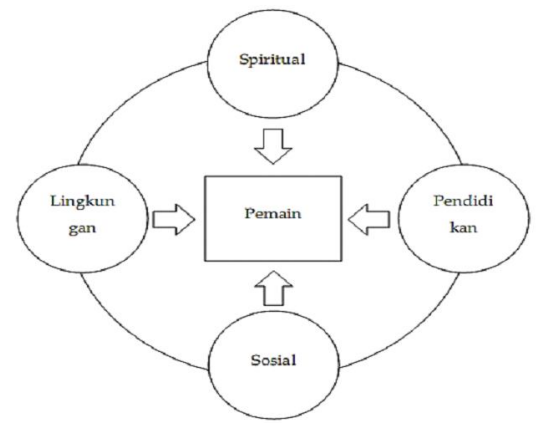

\section{Gambar 6. Faktor yang Melekat pada Pemain}

Selama ini akuntansi berupaya mengukur sesuatu yang abstrak tersebut dengan satuan moneter. Tetapi satuan moneter tidak selalu menjadi indikator terbaik. Satuan ini tidak dapat membingkai dengan tepat utilitas yang ada, misalnya harga transfer pemain. Harga transfer tersebut tentu saja tidak mengandung spiritualitas, pendidikan/pelatihan, sosial, dan lingkungan yang terinternalisasi dalam diri pemain. Lalu 
apakah harga transfer yang dijadikan pengukuran pemain dan diakui sebagai aset tersebut tepat? Padahal pemain sebagai manusia tergantung pada Tuhan. Kinerja manusia tidak dapat dipastikan di masa yang akan datang, sehingga tidak pas bila diakui sebagai aset (intangible aset).

\section{SIMPULAN}

Seluruh pembahasan dalam tulisan saya ini menuju pada satu hal yaitu faktor yang melekat pada pemain. Faktor ini tersembunyi dalam diri pemain. Faktor ini ada dan tidak pernah terekspos ke dalam laporan keuangan. Faktor ini merupakan dasar dari pembentukan pemain sepak bola sekaligus mengkritisi pemain sebagai aset. Faktor ini merupakan dasar yang baik untuk digunakan untuk membuat konsep akuntansi untuk pemain sepak bola karena faktor ini merepresentasikan apa yang saya maksud "gawane" pemain. Faktor ini menunjukkan bahwa pemain tidak etis bila diakui sebagai aset klub sepak bola.

Kesimpulan saya tersebut akan lebih kuat jika sepak bola tidak diindustrialisasikan. Industrialisasi sepak bola akan meruntuhkan nilai-nilai sosial-spiritual yang ada dalam sepak bola sehingga bingkai sepak bola menjadi kapitalisme yang selalu menyenangkan egoisme para pemilik modal. Orientasi sepak bola tidak lagi sebagai sebuah persatuan masyarakat, melainkan menjadi bisnis yang terus menerus mengejar laba. Para pemain hanya dijadikan alat untuk mencari keuntungan. Pemain tidak dianggap sebagai manusia yang seharusnya tidak pantas dijadikan sebuah komoditas jual beli (transfer pemain) lalu kemudian menganggapnya sebagai aset.

Menurut saya, konsep akuntansi yang melihat secara holistic ini merupakan konsep terbaik untuk saat ini. Konsep ini ditemukan berdasarkan fenomena yang ada dalam masyarakat dan refleksi diri untuk melihat secara menyeluruh kehidupan pemain sepak bola sebagai manusia baik dari spiritual dan material. Sudah saatnya akuntansi melihat sesuatu tidak hanya dari sudut pandang material, melainkan juga melihat dengan sudut pandang yang lebih luas dengan menggali hakikat yang tersembunyi dari manusia. Akuntansi tidak dapat lepas dari manusia yang memiliki dimensi yang berlapis.

\section{DAFTAR PUSTAKA}

Amir, E., \& Livne, G. 2005. Accounting, Valuation And Duration of Football Player Contracts. Journal of Business Finance \& Accounting, 549-586.

Bowles, S., \& Gintis, H. 1975. The Problem with Human Capital Theory - A Marxian Critique. The American Economic Review (dalam JSTOR), 74-82.

Devi, A.P. 2004. Akuntansi untuk Pemain Sepak Bola. Jurnal Akuntansi dan Keuangan Indonesia Vol. 1, 38-53.

Fattah, N. 2004. Ekonomi dan Pembiayaan Pendidikan. Bandung: Remaja Rosdakarya.

Flamholtz, E.G. 1969. The Theory and Measurement of Individual's Value To an Organization. Michigan: Ph.D Dissertation, University of Michigan. 
Goshunova, A. 2013. The Impact of Human Capital Accounting on the Efficiency of English Professional Football Clubs. Munich Personal RePEc Archive.

Hermanson, R.H. 1964. Accounting for Human Assets. Michigan, East Lansing: Occasional Paper No. 14 Michigan State University.

Johnson, S. 1990. Accounting To and For Employees.

Kurniawan, R., Mulawarman, A. D., \& Kamayanti, A. 2014. Biological Assets Valuation Reconstruction: A Critical Study of IAS 41 on Agricultural Accounting in Indonesian Farmers. Procedia Social and Behavioral Science.

Muhadjir, N. 2000. Metodologi Penelitian Kualitatif. Yogyakarta: Rake Sarasin.

Oprean, V.B., \& Oprisor, T. 2013. Accounting for Soccer Players: Capitalization Paradigm Vs. Expenditure. Procedia Economics and Finance.

Poernomo, J. 2011. Aremakita. Retrieved from Aremakita: http://aremakita.blogspot.com/ 2011/01/mengelola-sepakbola-indonesia-menjadi.html

Riharjo, I.B. 2011. Memahami Paradigma Penelitian Non-Positivisme dan Implikasinya dalam Penelitian Akuntansi. Jurnal Akuntansi, Manajemen Bisnis, dan Sektor Publik, 128-146.

Schultz, T.W. 1961. Investmen in Human Capital. The American Economics Review.

Siddik, M. H., \& Chariri, A. 2013. Mencari Format Laporan Keuangan yang Sesuai dengan Klub Sepak Bola di Indonesia: Studi Kasus pada Klub Sepak Bola Persema. Diponegoro Journal of Accounting, 1-11.

UEFA, T. 2012. UEFA Club Licensing and Financial Fair Play Regulations. EUFA.

Yin, R.K. 2004. Case Study Research. Jakarta: PT Raja Grafindo Persada. 